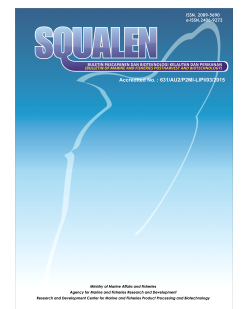

\title{
CHARACTERISTICS OF KAMABOKO FROM CATFISH (Clarias gariepinus) SURIMI PROCESSED WITH CARROT AND BEET ROOT AS FILLER AND NATURAL FOOD COLORANTS
}

\author{
Theresia Dwi Suryaningrum ${ }^{1 *}$, Hari Eko Irianto ${ }^{2}$, and Diah Ikasari1 \\ ${ }^{1)}$ Research and Development Center for Marine and Fisheries Product Processing and Biotehnology, \\ Jalan KS. Tubun Petamburan VI, Slipi, Central Jakarta 10260, Indonesia \\ ${ }^{2)}$ Research Center for Fisheries Management and Conservation Ministry of Marine Affairs and Fisheries, \\ Jalan Pasir Putih II, Ancol Timur, Jakarta 14430, Indonesia \\ Article history: \\ Received: 15 August 2015; Revised: 8 November 2015; Accepted: 23 November 2015
}

\begin{abstract}
The objective of the study was to investigate the effect of beet root and carrot as filler and natural food colourant on the chemical, physical and sensory properties of kamaboko. Kamaboko from catfish (Clarias gariepinus) surimi was processed with carrot (Daucus carota) and beet root (Beta vulgaris) at two concentrations (12 and $16 \%$ of surimi weight). Assesment was done on chemical (proximate, $\mathrm{pH}$ ), physical (folding test, WHC, gel strength and breaking force) properties as well as sensory evaluation. The results showed that kamaboko gel processed using beet root had better performance than kamaboko gel processed using carrot. Kamaboko processed using beet root has protein content, folding test, water holding capacity, gel strength, breaking force, and sensory characteristics (appearance, colour, odor, texture, and taste) better than kamaboko processed with carrot. Increasing concentration of filler only affect on the gel strength and breaking force of kamaboko processed with beet root. The best characteristic of kamaboko was obtained from kamaboko processed using beet root with concentration of $12 \%$. However, beet root was not recommended as colourant since the colour was not stable especially when stored at freezer.
\end{abstract}

Keywords: surimi, kamaboko gel, beet root, carrot, natural colourants

\section{Introduction}

Kamaboko is one of the most popular and traditional fish products from Japan. Processing kamaboko involves surimi as a main ingredient, starch as a filler and addition of sugar, salt and food colourants. The characteristics of kamaboko are having sweet taste, juicy and elastic texture due to the protein gel availability (Okada, 1985). Many studies had been conducted to find out the best composition of filler to produce good characteristics kamaboko. In spite of its elastic and juicy gel, kamaboko is also characterized by its attractive colour such as pink, green and purple. The synthetic food colourant that usually used are beta carotene for red, tartrazine for yellow, and fast green for green (Rohrig, 2015). However, consumer perception indicates that using natural food colorants ingredient would be safer and healthier. In addition, carrot and beet root are considered potential for food colorants (EI-Gharably, 2005).
Carrot and beet root are having some primary characteristics of pigmen, thus it can be also used for filler and coloring agent for kamaboko. Carrot has high carotenes pigmen which give bright orange color. This type of pigment is fat soluble and found in special pigment bodies called chromoplasts. The chemical structure of cartenoid is considered to be very stable and therefore is less affected by outside forces and doesn't change color very easily (Kay et al., 2014). The pigment is a type of anthocyanin, which has strong red color, one of them is betacyanin. Strack et al. (2003) reported that betalains are nitrogenous plant pigments and soluble in water. It consists of two sub class namely betacyanin and betaxanthin which characterized by red-violet and yellow-orange. Unlike the cartenoids in carrots, betacyanins are very easily and radically altered during most cooking processes. They are known to change color completely, especially with changes in $\mathrm{pH}$. Because anthocyanins are watersoluble, beets are susceptible to color changes in

${ }^{*}$ Corresponding author.

E-mail: theresiadwi@yahoo.com 
water cooking methods as well as roasting and frying (Kay et al., 2014)

According to Damian \& Oroian (2013) carrot is a good source of natural antioxidants, especially carotenoids and phenolic compounds. Carotenoids represent a large group of phytochemicals that may contribute to health and disease prevention. Furthermore, because of the high antioxidant activity, coloring food with carrot is useful for preventing cancer especially colon cancer. Meanwhile, beet root have long been used as medical purposes, primarily to prevent the risk of obesity, diabetic, heart disease and promotes a healthy complexion and hair, increased energy (Megan, 2015). It was recently discovered that natural food pigments of beet root can inhibit the cell proliferation of a variety of human tumor cells (Slavov et al., 2013). Beet root also contains high concentration of sugar, about 15-20\% (Nottingham, 2004), while total sugar in carrots is $5,6 \%$ and has three major types of sugars namely glucose, fructose and their polymer (Sharma et al., 2012). Therefore beet root and carrot suitable for kamaboko filler which tends to have sweet taste. Prabowo et al. (2013) had used beet as sausage filler and dye and showed that addition of beet with concentration of 5-15\% improved the product colour without changing its taste and texture. Moreover, study of the use of carrot for natural dye of empek-empek Jelawat fish (Leptobarbus hoevenii) showed that addition of carrot with consentration of $20 \%$ can be accepted by panelist (Evianty et al., 2014).

The utilization of carrot and beet as filler and natural food colourant will affect the chemical, physical properties and sensory characteristic of kamaboko gel. Therefore, this study aimed to investigate the effect of beet root and carrot as filler and natural food colourant on kamaboko produced from catfish surimi. This study is expected to result a useful information for the development of surimi based product, especially kamaboko using beet root and carrot as filler and natural colourants.

\section{Materials and Methods}

\subsection{Materials}

Frozen surimi produced from catfish (Clarias gariepenus) with size of more than $1 \mathrm{~kg}$ was used as raw material to produce kamaboko. Beet root with weight of $180-230 \mathrm{~g}$ each and Australian carrot with size of 220-240 $\mathrm{g}$ were used as kamaboko filler. Other ingredients used were salt, egg white, carrageenan, STTP, MSG, sugar and emulsifier. In addition, chemicals for chemistry analysis were also used.

\subsection{Methods}

\subsubsection{Surimi of catfish production}

Surimi was made by washing minced meat of catfish three times using $0,5 \% \quad \mathrm{NaHCO}_{3}$ solution in cool temperature $\left( \pm 5^{\circ} \mathrm{C}\right)$. The mince fish was prepared by deboner machine (Bibun, Japan) with 0,2 mm diameter of holes. Washing process was done using water with ratio of water: meat $=5: 1$ for 15 minutes. In the third washing process, $0,5 \%$ of $\mathrm{NaHCO}_{3}$ solution was replaced by $0,5 \%$ of salt solution. Surimi was then reduced its moisture content by using meat dehydrator (Bibun, Japan) and rifener to remove scales and spines using the stainner machine (Bibun, Japan). $4 \%$ of sorbitol, $4 \%$ of sucrose and $0.2 \%$ of poliphosphat were then added as cryoprotectan and mixed for 10 minutes using mixing and kneading machine (Bibun, Japan). The surimi dough was then shaped into block and then frozen slowly using mechanical freezer, and stored for a week in cold storage.

\subsubsection{Beet root and carrot paste production}

Beet root and Carrot were peeled, washed and cut into smaller size, then steamed for 30 minutes. After steaming, beet root and carrot were mashed using shredder machine (Phillip) until become a soft paste.

\subsubsection{Preparation of kamaboko gel production}

The process of kamaboko gel making was referred to the previous study using formula as follow : $1,5 \%$ of salt; $5 \%$ of egg white; $1 \%$ of carrageenan; $0,4 \%$ of STTP, $0,5 \%$ of monosodium glutamate; $3 \%$ of sugar; $0,2 \%$ of emulsifier and $12 \%$ of tapioca as a filler, $10 \%$ of ice flake (Suryaningrum \& Ikasari, 2010). Based on previous research and considering that beet root and carrot has high moisture content, the concentration of filler was modified to $12 \%$ and $16 \%$ of surimi weight. Half thawed surimi from catfish was grinded using a mixing and kneading machine, and than $2 \%$ of salt was added. Surimi was then stirred until the sticky paste was formed and then gradually the material such as egg white, sugar, MSG, carrageenan, fat emulsifier, beet root or carrot paste and ice flakes was added and stirred for 15 minutes. The resulting dough was shaped into cilyndrical with a diameter of $50 \mathrm{~mm}$ and aproximately $200 \mathrm{~mm}$ in length and wrapped with HDPE plastic and both of the end of plastic were tied. The filled plastic samples were heated in two stages, using $40-50{ }^{\circ} \mathrm{C}$ for 20 minutes in waterbath for gel setting and then 
steamed at temperature of $90-95^{\circ} \mathrm{C}$ for 20 minutes to form kamaboko gel. Finally kamaboko gel were taken out and immediately cooled in an ice water and then room temperature. The product stored at chilling room $\left( \pm 2^{\circ} \mathrm{C}\right)$ over night.

\subsubsection{Research variable}

Variable used in the study were types of filler (beet root and carrot) and concentrations of filler (12\% and $16 \%$ of surimi weight). Thus, combination of treatment became: beet root $12 \%(B A)$, beet root $16 \%(\mathrm{BB})$, carrot $12 \%(\mathrm{WA})$ and carrot 16\% (WB).

\subsubsection{Chemical analysis}

Proximate analysis was conducted using Indonesian National Standart (BSN, 2006) moisture content (SNI 01-2354.3-2006), ash content (SNI 012354.3-2006), protein content (SNI 01-2354.3-2006) and fat content (SNI 01-2354.3-2006) on raw material (surimi, beet root, and carrot), $\mathrm{pH}$ of product was measured using pH meter (Yunizal et al., 1998).

\subsubsection{Physical test and textural analysis}

Physical test was done for folding test (Clucas \& Ward, 1996), water holding capacity (WHC) (Xiong et al., 2009), textural properties (BSN, 2006). Folding test was conducted by slicing the kamaboko into 4-5 $\mathrm{mm}$ then folded to observe that there was a broken texture. The kamaboko was categorized to be elastics if it can be folded many times without any split. Texture analysis of the gels was carried out using a texture analyzer Model TA-XT2 plus (Stable Micro Systems, Surrey, England). Gels kept at $4^{\circ} \mathrm{C}$ were equilibrated at room temperature $\left(22^{\circ} \mathrm{C}-25^{\circ} \mathrm{C}\right)$ before analysis. Cylindrical samples, $2.5 \times 3.0 \mathrm{~cm}$, were prepared and placed in the texture analyzer equipped with a spherical plunger $(5 \mathrm{~mm}$ diameter; $60 \mathrm{~mm} / \mathrm{min}$ depression speed). Analysis were performed at least in triplicate. Gel strength was expressed as the product of breaking force and deformation (Arfat \& Benjakul, 2012)

\subsubsection{Colour analysis}

The colour of the samples was measured using chromameter (Minolta Chromameter, Model CR 310, Tokyo-Japan), in which the result was performed with $L^{*}, a^{*}$ and $b^{*}$ value. The parameter $L^{*}$ is an approximate measurement of brighness/lightness where $L 100$ showed white colour and $L 0$ showed black colour. Positive values for $\mathrm{a}^{*}$ showed by redness colours and negative value for greeness ones. Positive value for $b^{*}$ indicated by yellowness colours and negatif value for the blueness ones (Pankay, 2013).

\subsubsection{Sensory evaluation}

Sensory evaluation was carried out by $15 \mathrm{semi}$ skilled panelists. The panelists were asked to evaluate apparence, odor, texture and taste by using scoring test (BSN, 2006).

\subsubsection{Statistical analysis}

The study was done in triplicates and the data obtained were then statistically analyzed using software SPS 16. If there was a significant effect identified, analysis was continued with Duncan test to obtain the best formula of kamaboko.

\section{Results and Discussion}

\subsection{Proximate Analysis of Raw Material and Physical Properties of Surimi}

Results of proximate analysis of beet root, carrot, and surimi made from catfish as raw material are presented in Table 1. Moisture, ash and protein content of surimi made from catfish were still well within the standard surimi according SNI 01-2694-

Table 1. Proximat analysis of raw material dan physical properties of surimi

\begin{tabular}{lrrr}
\hline Parameters & Surimi made from catfish & \multicolumn{1}{c}{ Beet root } & \multicolumn{1}{c}{ Carrot } \\
\hline Water content $(\%)$ & $73.37 \pm 0.8$ & $87.58 \pm 0.18$ & $88.29+0.03$ \\
Ash content $(\%)$ & $0.68 \pm 0.14$ & $1.87 \pm 0.02$ & $1.51 \pm 0.03$ \\
Protein content $(\%)$ & $13.64 \pm 0.58$. & $1.6 \pm 0.34$ & $1.28 \pm 0.46$ \\
Fat content $(\%)$ & $7.38 \pm 0.97$ & $0.1 \pm 0.01$ & $1.30 \pm 0.03$ \\
Fiber content $(\%)$ & - & $13.6 \pm 0.45$ & $4.11 \pm 0.46$ \\
Carbohydrate $(\%)$ & $4.93 \pm 0.83$ & $8.85 \pm 0.15$ & $7.62 \pm 0.14$ \\
by diferent & 744.05 & - & - \\
Gel strength $\left(\mathrm{g} / \mathrm{cm}^{2}\right)$ & AA & - & - \\
Folding test & & & \\
\hline
\end{tabular}


2006. The moisture content of industrial surimi should be less than $85 \%$ and for top-grade surimi, the content should be less than $82 \%$. (Clucas \& Ward, 1996) However, the fat content of surimi made from catfish was high $(>5 \%)$. This is allegedly can affect the gel formation during processing kamaboko.

The gel strength of surimi used in this study was $744,05 \mathrm{~g} / \mathrm{cm}^{2}$. This value is beyond the range of standard that has been established for surimi, with $600 \mathrm{~g} / \mathrm{cm}^{2}$. In addition, folding test surimi made from catfish resulted that surimi was classified to $A A$ grades, means that the surimi has high quality texture. Surimi made from catfish has water holding capacity of $14,65 \%$ and $\mathrm{pH} 7,43$.

Beet root has higher fiber and carbohydrate contents compared to carrot, while moisture, ash and protein contents, of beet root and carrot were not significantly different.

\subsection{Proximate Value of Kamaboko Gel}

Proximate value of kamaboko gel at various treatments are presented in Table 2. Table 2 showed that the moisture and ash contents of gel kamaboko using beet root and carrot as filler were not significantly different $(P>0.05)$. The average value of protein contents showed that kamaboko using beet root as filler was higher $(P<0.05)$ than kamaboko processed with carrot. The use of higher concentration of filler did not affect protein content of kamaboko $(P>0.05)$. Addition of carrot $12 \%$ as filler produced kamaboko with lower fat content $(P<0.05)$ than kamaboko processed with beet root $12 \%$. Increasing of concentration of filler in kamaboko did not affect fat content of kamaboko.

\section{3. $\mathrm{pH}$}

$\mathrm{pH}$ is one of the most important factors in producing strong elastic kamaboko gels. The optimal $\mathrm{pH}$ for strong gelation is approximately 7.0-7.5 for white meat fishes (Ni et al., 2001). It was reported that the water holding capacity of protein gel significantly occurred at $\mathrm{pH}$ of $6-7$, while at $\mathrm{pH}$ above 7 will result in weaker gel (Lanier et al., 2005).

The study resulted $\mathrm{pH}$ of kamaboko varies between 7.24-7.38. This value of $\mathrm{pH}$ is optimum for gel formation as described by $\mathrm{Ni}$ et al. (2001), which mentioned that the optimum pH for gel formation is between 7.0 -7.5. Study showed that $\mathrm{pH}$ of kamaboko processed with beet root as filler resulted in lower $\mathrm{pH}$ value, significantly different $(\mathrm{P}<0.05)$ compared to $\mathrm{pH}$ of kamaboko processed with carrot. This is because beet contains higher vitamin C for $30 \mathrm{mg} / 100 \mathrm{gr}$ (Craig, 2004) compared to carrot which only contained 7,20 $\mathrm{mg} / 100 \mathrm{~g}$ vitamin C (Favell, 1998) which are known to be acid. But increasing the concentration of filler tended to increase $\mathrm{pH}$ value, however, the increase was not significantly different $(P>0.05)$.

\subsection{Physical Parameters of Kamaboko}

The physical parameters of kamaboko was observed for folding test, water holding capacity, gel strength and breaking force of kamaboko.

\section{a. Folding test}

Folding test is one of parameters that reflects the gel strength (Venugopal, 2006). Result of folding test of kamaboko gel showed that using carrot and beet root as filler produced kamaboko gel with grades of $A A$, means that the gel was not split out when folded for 2 times. This is because of the surimi used for kamaboko material also had AA grades, which means elastic. The addition of beet root and carrot with concentration of $12-16 \%$ did not affect the change of gel elasticity of kamaboko gel. According to Lee et al. (1992) the formation of protein gel matrix in kamaboko is affected by $\mathrm{pH}$ and water availability where interaction between protein and water will further affect the textural characteristics, juiciness and tenderness. Beet and carrots have high moisture content $87.58 \%$ and $88.29 \%$ respectively, which will affect the folding ability, cohesiveness and elasticity of kamaboko (Tanikawa et al., 1985).

Tabel 2. Proximate value of gel kamaboko processing with carrot and beet root as a filler

\begin{tabular}{lcccr}
\hline Treatment & $\begin{array}{c}\text { Moisture } \\
\text { content (\%) }\end{array}$ & $\begin{array}{c}\text { Ash } \\
\text { content (\%) }\end{array}$ & $\begin{array}{c}\text { Protein } \\
\text { content (\%) }\end{array}$ & \multicolumn{1}{c}{$\begin{array}{c}\text { Fat } \\
\text { Content (\%) }\end{array}$} \\
\hline Beet root 12\% & $72.25 . \pm 1.61^{\mathrm{a}}$ & $1.88 \pm 0.08^{\mathrm{a}}$ & $12.65 \pm 0.35^{\mathrm{a}}$ & $6.59 \pm 0.41^{\mathrm{b}}$ \\
Beet root 16\% & $72.06 \pm 1.40^{\mathrm{a}}$ & $2.07 \pm 0.13^{\mathrm{a}}$ & $12.28 \pm 0.71^{\mathrm{a}}$ & $6.16 \pm 0.88^{\mathrm{ab}}$ \\
Carrot 12\% & $73.05 \pm 1.46^{\mathrm{a}}$ & $2.07 \pm 0.04^{\mathrm{a}}$ & $11.05 \pm 0.98^{\mathrm{b}}$ & $5.54 \pm 0.12^{\mathrm{a}}$ \\
Carrot 16\% & $72.87 \pm 1.17^{\mathrm{a}}$ & $2.09 \pm 0.08^{\mathrm{a}}$ & $11.48 \pm 0.43^{\mathrm{b}}$ & $6.11 \pm 0.73^{\mathrm{ab}}$ \\
\hline
\end{tabular}

Note: Different letters in the same coloumn indicate significant different $(\mathrm{P}<0.05)$ 


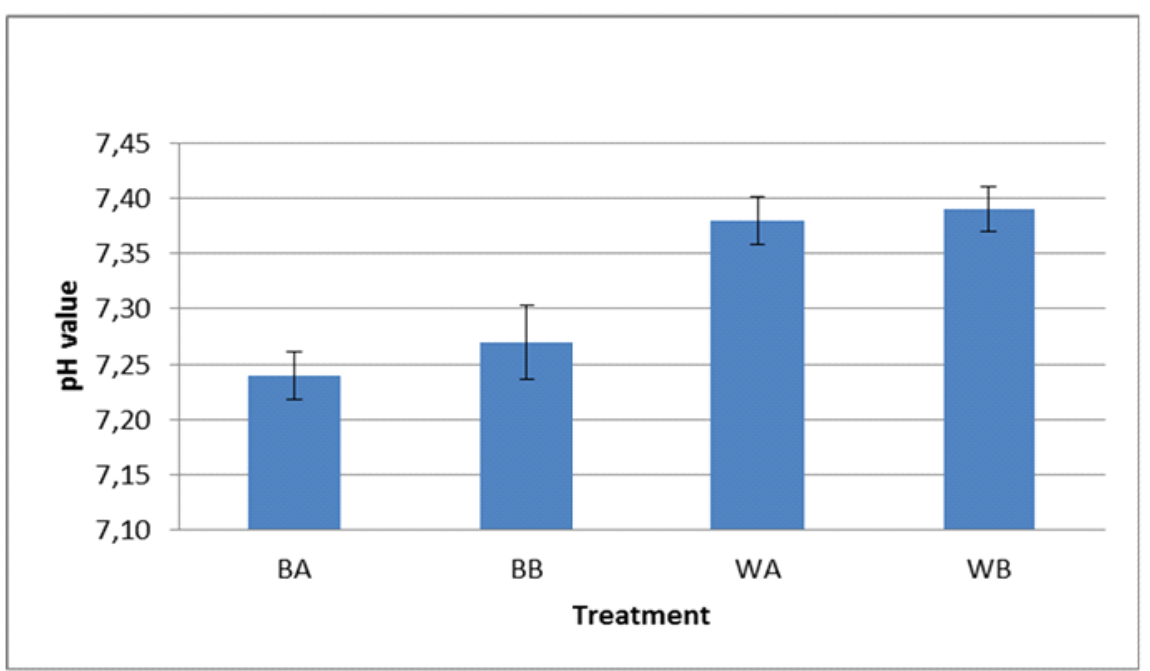

Note: BA: Beet root 12\%, WA: Carrot 12\%; BB: Beet root $16 \%$, WB: Carrot $16 \%$.

Figure 1. pH of kamaboko at various treatments.

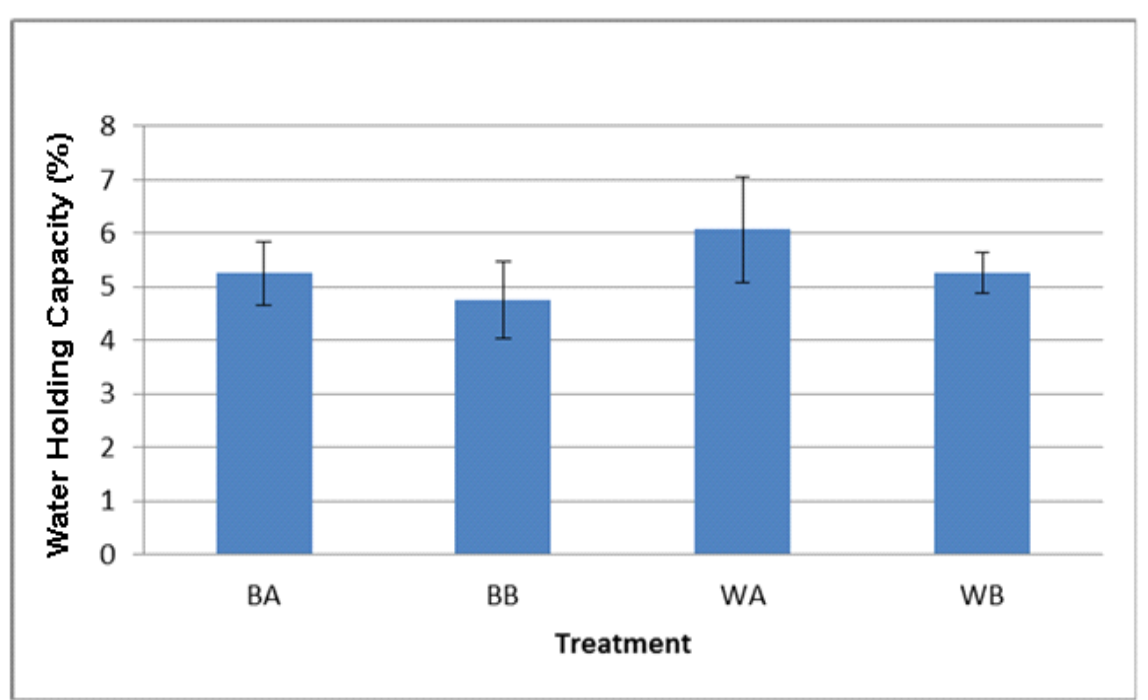

Note: BA: Beet root 12\%, WA: Carrot 12\%; BB: Beet root 16\%, WB: Carrot $16 \%$.

Figure 2. Water holding capacity of kamaboko at various treatments.

\section{b. Water holding capacity (WHC)}

The water holding capacity (WHC) is defined as the ability of muscle to retain its own or added water of surimi. The water-holding capacity of surimi is related to myofibrillar proteins. Interactions between proteins and water will affect the nature of surimi texture, juiciness and tenderness, color, and taste (Ingadotir \& Kristinsson, 2010). WHC usually reflects the extent of denaturation of proteins and the water content. Result of the study showed that water holding capacity of kamaboko processed with carrot were 6.07-6.96\% which were significantly better than kamaboko processed with beet root which only 5.25-4.75\%, $(P<0.05)$ (Figure 2). Higher WHC value indicates the ability of gel binding the water. According to Benjakul et al. (2003) during the process of "setting" at temperature of $40^{\circ} \mathrm{C}$, proteins are experiencing denaturation, then gradually to form a network that can absorb water. The addition of carrots which has higher water content as a filler, can increase protein crosslinking, thus forming a stronger network with higher water binding capacity. However higher concentration of beet added to the formulation did not significantly affect the water holding capacity of kamaboko gel. Meanwhile, the higher concentration of carrot added to the formulation influenced to the decrease of water holding capacity of kamaboko. In this study WHC of the products were quite low, cooking with high temperature can reduce water holding capacity. High cooking temperatures can 
accelerate the decrease in $\mathrm{pH}$ and reduce water holding capacity due to the increase of protein denaturation (Skipnes et al., 2007).

\section{c. Gel strength}

Gel strength and elasticity are important quality parameters for kamaboko. Results of gel strength analysis of kamaboko processed with different concentration of filler are presented in Figure 3. Average of gel strength of kamaboko processed with beet root is higher than kamaboko gel processed with carrot. The highest gel strength was obtained from kamaboko processed with beet root $12 \%$, reached to $1.856 \mathrm{~g} / \mathrm{cm} 2$, while the lowest was obtained from kamaboko processed with carrot $12 \%$, with $1.052 \mathrm{~g} /$ $\mathrm{cm} 2$.

The statistical analysis showed that types of filler significantly affected to the gel strength of kamaboko $(\mathrm{P}<0.05)$, while the concentration level of filler did not significantly influence the gel strength of kamaboko $(P>0.05)$. Higher gel strength value of kamaboko processed with beet root as filler can be attributed to its high starch content. In 100 grams of beet root contained $8.85 \mathrm{~g}$ of starch, while in carrot was only $7.62 \mathrm{~g}$ of starch (Table 1). The heating process of kamaboko gel can cause several change to the starch characteristics, such as the swollen of granules, water absorption, thus improving the texture or gel strength (Yang \& Park, 1998). According to Campo \& Tovar (2008), starch affects the rheological properties of kamaboko gel, addition of starch will absorb a lot of water and form more elastic kamaboko with good water holding ability and a greater strengthening ability of starch/surimi system Besides, this beet root has higher fiber content (13,6\%) compared to carrot $(4,11 \%)$. According to Almatsier (2009) there are two kinds of crude fiber, which is insoluble in water and soluble in water. Water-soluble fibers tend to bind with water to form a gel network, increasing elasticity dan strengthening of kamaboko gel.

\section{d. Breaking force}

Generally, reliable assessment of the textural characteristics of surimi product are obtained from the results of breaking force and gel strength (Park, 2005). Breaking force is the limit of elasticity of the gel that shows the amount of resistance to deformation gel becomes torn. Influence of type and concentration of filler are presented in Figure 4. The highest breaking force was obtained from kamaboko processed with beet root $12 \%$ meaning that kamaboko processed with beet root $12 \%$ has higher gel strength and elasiticity compared to other. Kamaboko processed with beet root has higher breaking force $(P>0.05)$ than kamaboko processed with carrot. While the concentration of fillers only affect kamaboko processed with beet root. The breaking force of kamaboko gel decreased significantly with the increasing concentration of beet root. Increasing of beet root concentration affected to the decrease of forming ability, gel strength and elasticity. It can be associated with the high starch and fiber content found in beet root.

\subsection{Colour Analysis}

The result of colour analysis using Chromamometer is presented in Table 3. It was appeared that kamaboko processed with carrot had higher $L$ value,

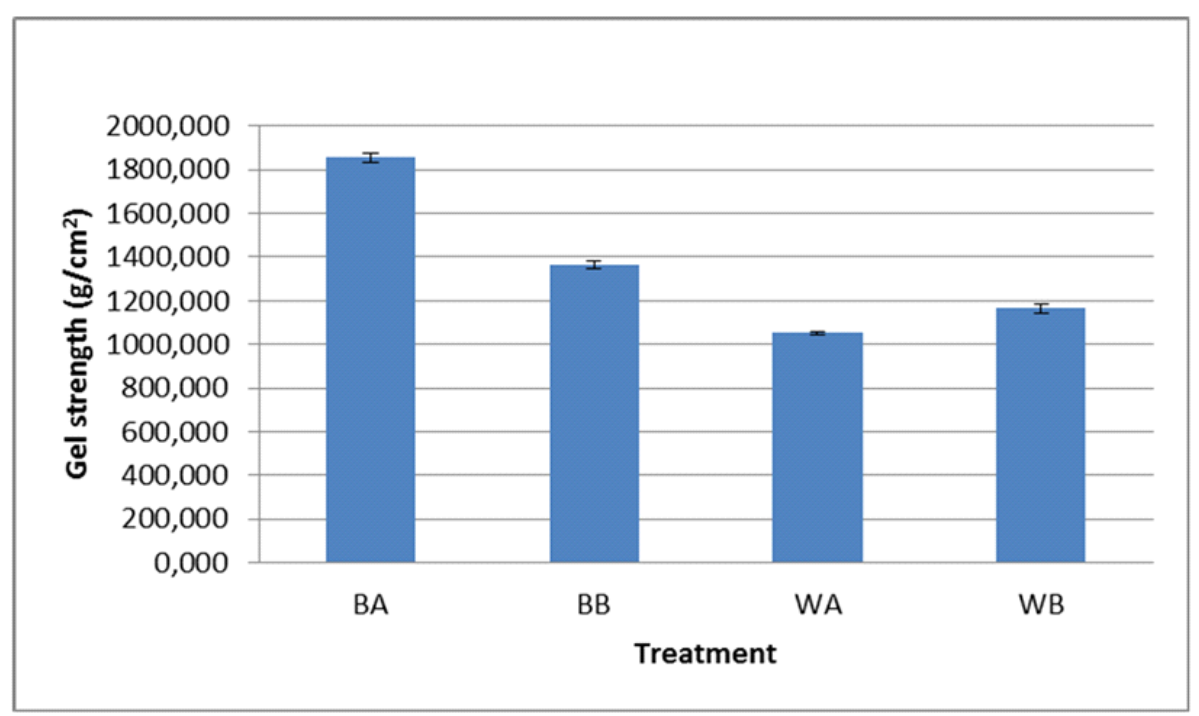

Note: BA: Beet root 12\%, WA: Carrot 12\%; BB: Beet root 16\%, WB: Carrot 16\%.

Figure 3. Gel strength of kamaboko at various treatments. 


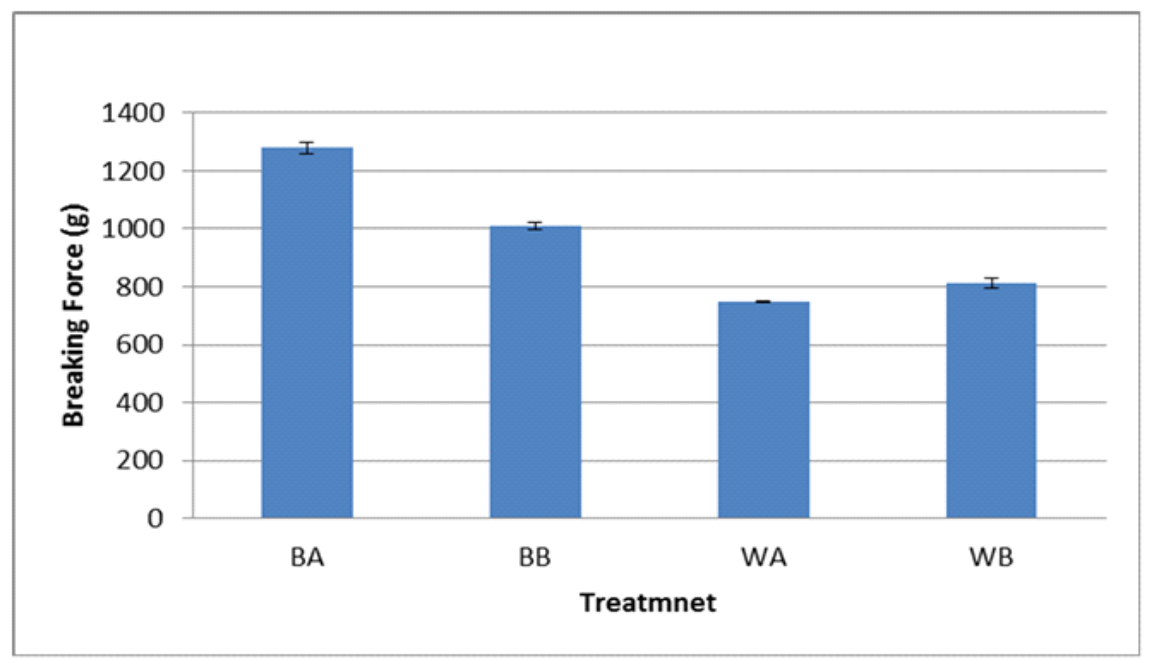

Note: BA: Beet root 12\%, WA: Carrot 12\%; BB: Beet root 16\%, WB: Carrot 16\%.

Figure 4. Breaking force of kamaboko at various treatments.

meaning that it was brighter than kamaboko processed with beet root. The statistical analysis showed that types of filler significantly affected the colour of kamaboko gel $(P<0.05)$ while the concentration level of filler did not significantly influence the appearance of kamaboko $(P>0.05)$. The intensity of the color differences caused the kamabako processed with beet root had a reddish yellow color like a turmeric yellow. Beet root contains betalain pigmen which has purplish red colour. This pigment is very easily and radically altered during most cooking processes (Slavov et al., 2013). Kamaboko processed with beet root before steaming had red purple colour, but after steaming the purple colour changed to be reddish-yellow colour. The reddish-yellow colour of kamaboko precessed with beet root was shown by lower $\mathrm{a}^{+}$and higher $\mathrm{b}^{+}$values, and these values were significantly different with kamaboko processed with carrot. Kamaboko processed with carrot had strong yellowness colour compared to kamaboko processed with beet root as indicated by higher $\mathrm{b}^{+}$value. The pigment carotenoid from carrot is more stable and less affected by outside forces and doesn't change color very easily (Assous, 2014)

\subsection{Sensory Evaluation of Kamaboko Gel}

The sensory evaluation of kamaboko gel was conducted for scoring test on parameter of appearance, colour, odor, texture and taste.

\subsubsection{Appearance}

Scoring test on parameter of appearance of kamaboko gel showed that type of filler significantly affected kamaboko's appearance $(P<0.05)$, while the concentration level of filler did not significantly influence the appearance of kamaboko ( $P>0.05)$. Kamaboko processed with beet $12 \%$ had higher score (5.36) compared to kamaboko processed with carrot $12 \%$ (4.73). Duncan test showed that only kamaboko processed with beet root $12 \%$ significantly different with other treatments.

Table 3. Results of colour analysis of kamaboko gel from various treatments using chromameter

\begin{tabular}{llrr}
\hline Treatment & \multicolumn{1}{l}{ L Value } & $\mathbf{a}^{+}$(redness) & $\mathbf{b}^{+}$(yellowness) \\
\hline Beet root 12\% & $60.63 \pm 4.35^{\mathrm{a}}$ & $14.90 \pm 0.05^{\mathrm{a}}$ & $34.93 \pm 1.00^{\mathrm{a}}$ \\
Beet root 16\% & $59.70 \pm 0.33^{\mathrm{a}}$ & $18.73 \pm 0.61^{\mathrm{a}}$ & $35.56 \pm 0.58^{\mathrm{a}}$ \\
Carrot 12\% & $76.94 \pm 0.68^{\mathrm{b}}$ & $8.87 \pm 1.02^{\mathrm{b}}$ & $46.37 \pm 2.22^{\mathrm{b}}$ \\
Carrot 16\% & $76.60 \pm 0.76^{\mathrm{b}}$ & $9.38 \pm 0.53^{\mathrm{b}}$ & $48.41 \pm 1.55^{\mathrm{b}}$ \\
\hline
\end{tabular}

Note: Different letters in the same coloumn indicate significant different $(\mathrm{P}<0.05)$ 
Appearance is related to the ability of filler to absorb water, thus producing clearer and shiny product. Kamaboko which can absorb more water will be completely swolen, producing transparent and shiny gel with soft texture surface (Zang et al., 2012). This can be correlated with the water content of the kamaboko processed with beet root which had higher water content compared to kamaboko processed with carrot. Besides, the appearance of kamaboko processed with beet root had redish-yellow colour which was preffered by panelis. Higher concentration of filler added to the formula resulted in lower value appearence of kamaboko. However, statistical analysis showed that the effect of level concentration of filler only appeared in kamaboko processed with beet root, While in kamaboko processed with carrot, this effect did not affect the panelist preferrence.

\subsubsection{Colour}

Panelists gave highest score of colour to the kamaboko gel processed with beet root $16 \%$, with
5.27 means that between slightly like and like. Kamaboko gel processed with beet root had higher intensity of redness yellow colour compared to kamaboko processed with carrot which has light yellow colour. Panelists gave score to kamaboko processed with carrot between 4.55-4.64, meaning between neutral to slightly like, while panelists gave score kamaboko processed with beet root between 5.09- 5.27. The statistical result showed that type of filler significantly affected to the colour of kamaboko $(P<0.05)$. Meanwhile, the concentration of filler being used did not significantly influenced the panelist preference on the color of kamaboko. The result of score given by panelists on the colour of kamaboko is presented in Figure 5.

Basically, the colour of beet root is not stable and its change is affected by temperature and $\mathrm{pH}$ (Kay, 2014). Before cooked, the dough had an attractive purple colour. After cooked at above $80^{\circ} \mathrm{C}$, the purple colour changed into redness yellow colour, which is resemble to the curcumin colour. When kamaboko

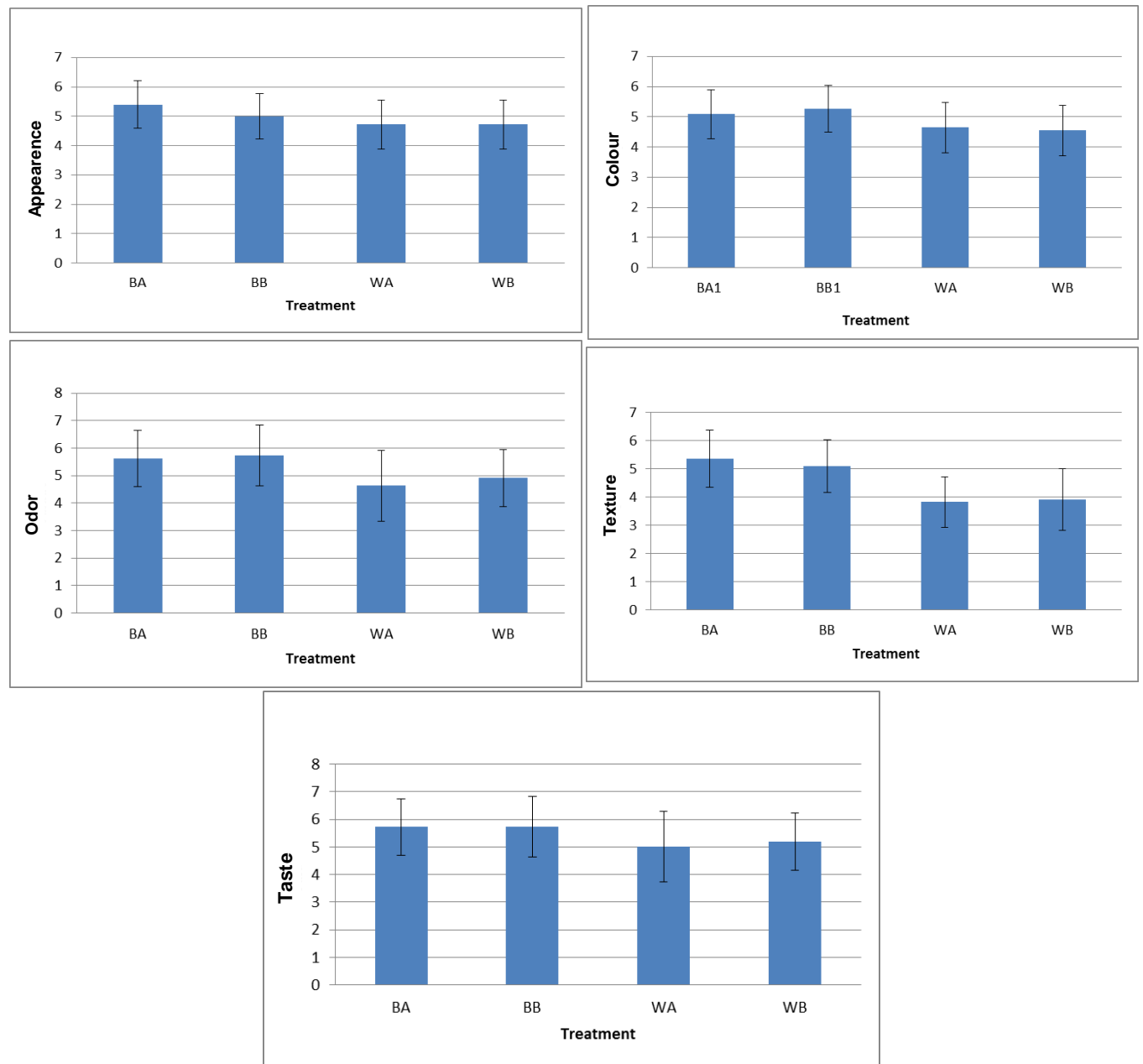

Note: BA: Beet root 12\%, WA: Carrot 12\%; BB: Beet root 16\%, WB: Carrot 16\%.

Figure 7. Skoring test of apparence, colour, odor, texstur, taste of kamaboko at various treatment. 
was freezed, the redness yellow colour will be changed again into purple. However, the change was not completely thus affecting the kamaboko's appearance. This result is in accordance with the study conducted by Osornio \& Chava (1998) in Prabowo (2013) which showed that beet as natural colourants degraded 40$50 \%$ when it was exposed to temperature of $0^{\circ} \mathrm{C}$ eventhough it was packed with polyvinyl chloride packaging. Therefore, kamaboko processed with beet is recommended to be stored at chilling temperature.

\subsubsection{Odor}

Generally, the odor of kamaboko is very complex, mixing between sweet smell of the breakdown of carbohydrate and savory smell from the fish due to heating process. During heating process, the specific aroma will be created due to combination between maillard reaction and volatile compound that is smell by our nose. Observation on the kamaboko gel odor showed that kamaboko processed with beet root resulted in odor that was preferred by panelist compared to the odor of kamaboko processed with carrot. The average score of kamaboko gel processed with beet root $12 \%$ was 5.36 , meaning that between slightly like and like. Meanwhile, kamaboko processed with carrot had lower score, with 3.82, meaning that the panelist tended not to like the product. Statistical result analysis showed that different type of filler resulted in odor of kamaboko which were significantly different $(P<0.05)$. The odor of kamaboko processed with beet tended to be preferred by panelist because it is more sweet odor due to carbohydrate breakdown into isomers by reducing sugar due to heating process. In contrast, the odor of kamaboko processed with carrot did not preferred by panelist due to the availability of a slightly unpleasant odor in the kamaboko. In addition, the concentration of filler being added to the kamaboko formula did not seem to affect the odor of kamaboko.

\subsubsection{Texture}

Kamaboko is characterized by its elastics texture, formed by reaction between protein myofibril with salt during mixing process. Observation to the texture of kamaboko showed that kamaboko processed with beet root $16 \%$ resulted in texture preferred by panelist compared to other treatments. Panelist gave score of 5.73 , meaning that they tended to like the product. Meanwhile, kamaboko processed with carrot $16 \%$ had score only 4.91 , meaning that panelist said neutral to slightly like.

Statistical analysis showed that type of filler significantly affected the texture of kamaboko
$(P<0.05)$, while the concentration of filler did not give an effect onto the texture of kamaboko $(P>0.05)$. Kamaboko processed with beet root resulted in elastics texture and was preferred by panelist. Beet root is a kind of potato, which has starch granule with bigger size, thus absorbing much water and affecting to the elasticity of kamaboko.

\subsubsection{Taste}

Kamaboko processed with beet and carrot resulted in sweet and juicy taste. This taste is the expected characteristics of kamaboko in the final product. Panelist preferred the taste of kamaboko processed with beet root compared to carrot. This showed by the score given to kamaboko processed with beet root, with 5.73 (tended to like), which was higher than the score given to kamaboko processed with carrot, with only 5.18 (slightly like). Statistical data showed that type of filler significantly affected the taste of kamaboko $(P<0.05)$, while concentration of filler did not influence the taste of kamaboko. Beet root is known to have higher sugar content (15-20\%) (Nottingham, 2004), compared with carrot only 5.6\%. The higher sugar content causing the kamaboko processed with beet root had sweet taste which was preferred by panelist.

\section{Conclusions}

Based on study results, it can be summarized that kamaboko processed with beet root as filler and colourant showed better performance compared to kamaboko processed with carrot. Kamaboko processed with beet root had higher protein content, gel strength, breaking force and sensory parameters that were preferred by panelist. Increasing concentration of filler resulting in the decrease of gel strength, and breaking force on kamaboko gel processed using beet root. Therefore, better characteristics were obtained from kamaboko processed with beet root $12 \%$. However, beet root was not recommended as colourant since the colour was not stable especially when stored at freezer.

\section{References}

Almatsier, S. (2009). Basic Prinsipal of Nutrition. PT Gramedia Pustaka Utama, Jakarta.

Assous M.T.M, Abdel-Hady M.M., \& Medany, G.M. (2014). Evaluation of red pigment extracted from purple carrots and its utilization as antioxidant and natural food colorants. Annals of Agricultural Science, 59(1), $1-7 A$.

Arfat Y.A. \& Benjakul. S. (2012). Gelling Characteristics of Surimi from Yellow Stripe Traveling (Selaroides leptolepis). International Aquatic Research, 4(5): 113. 
Badan Standardisasi Nasional (BSN). (2006). SNI 01.2354-2006. Indonesia National Standard. Chemical Test Method in Fishery Product.

Benjakul, S., Chantarasuwan, C., \& Visessanguan, W. (2003). Effect of medium temperature setting on gelling characteristics of surimi from some tropical fish. Food Chemistry, 82: 567-574

Campo-Deaño, L. \& Tovar, C.A. (2008). Influence of the starch content in the viscoelastic properties of surimi gels. J. Food Eng., 84: 140-147.

Clucas, I.J. \& Ward, A.R. (1996). Post-harvest fisheries development: A Guide to Handling, Preservation, Processing and Quality. Natural Resources Institute. $443 \mathrm{pp}$

Craig, S.A. (2004). Betaine in human nutrition. The American Jurnal of Clinical Nutrition. 80(3): 539-549

Damian, C. \& Oroian, M. (2013). Effect of thermal treatment on antioxidant activityand colour of carrot purées, Versita, 24 (1): 35-38

Evianty, S.T., N. Ira Sari. N.I., \& Sumarto. (2014). Study on the consumer acceptance of empek-empek Jelawat fish (Leptobarbus hoevenii) added with carrot I (Daucus carota). JOM: 1-11

El-Gharably, A.M.A. (2005). Characterization of anthocyanin pigments extracted from grape skins and its potential uses as antioxidant and natural food colorants. J. Home Econ., Minufiya Univ. 15, 51-70.

Favell. D.J. (1998). A comparation of Vitamin C content of fresh and frozen vegetable. Food Chemistry. 62(1): 59-64

Ingadottir, B. \& Kristinson, H.G. (2010). Gelation of protein isolates extracted from tilapia light muscle by pH shift processing, Food Chemistry. 118: 780-798.

Kay B., Brownlee, L., Glover, A., \& Ma, O. (2014). The Effect of $\mathrm{pH}$ and Heat on Vegetable Pigment. Retrieved on $2^{\text {nd }}$ November 2015, from http.biofood tripod.com.

Lanier, T.C., Carvajal, P., \& Yongsawatdigul. J. (2005). Surimi gelation chemistry. In Park J.W. Surimi and Surim Seafood $2^{\text {nd }}$ edition. Boca Raton FL. CRC. Press pp: 345-490.

Lee, C.M., Wu, M.C., \& Okada, M. (1992). Ingredient and Formulation Technology for Surimi based Product In. Lanier, T.c \& Lee, C.M., (eds) Surimi Technology M. Dekker, New York. based. Hongkong. 273-302.

Megan. W. (2015). Beetroot Health Benefid Nutrition Information. Retrieved on $2^{\text {nd }}$ November 2015 from www.Medicaltoday.com.

Ni, S., Nozawa, H., \& Seki, N. (2001). Effect of pH on the gelation of walleye pollack surimi and carp actomyosin pastes. Fisheries Science, 67(5): 920927.

Nottingham, S. (2004). Beetroot. Retrieved on $2^{\text {nd }}$ November 2015 from www.stephannottinghm.co.uk. beetroot.htm

Okada. M. (1985). Ingredient on gel texture. Proceedings of the International Symposium on Engineered
Seafood Including Surimi. 19-21 Nov 1985 Seattle, Washington. pp. 515-530.

Prabowo. D.H. (2013) . Effect of beet (Beta vulgaris. L) as natural dyes and filler on the physical, chemical and sensory characteristics of vegetable sausage. Skripsi. Teknologi Hasil pertanian Univ Sebelas Maret. Published on Line 1 Oktober 2013. Retrieved on 23 March 2015.

Park. (2005). Surimi and Surimi Seafood 2nd Edition. CRC Press. Florida USA.

Pankay B. (2013). Colour Measurement and Analysis in Fresh and Processed Food a Riview. Food Bioprocess Technol. 6: $36-60$.

Skipnes D., Østby M. L., Hendrickx M. E. 2007: A method for characterising cook loss and water holding capacity in heat treated cod (Gadus morhua) muscle, Journal of Food Engineering, 80(4): 1078-1085.

Strack D., Vogt T., Schliemann W.(2003): Recent advances in betalain research. Phytochemistry, 62: 247-269.

Sharma K.D, Karki, S, Thakur.N.S., \& Attri, S. (2012). Chemical composition, Functional and Processing of Carrot a Rieview. J. Food Sci Technol 49 (1) 22-32.

Rohrig. B. (2015). Chemistry of Food Colourings. Chem Matter online. Retrieved on $2^{\text {nd }}$ November 2015.

Suryaningrum, T.D. \& Ikasari. D. (2010). Effect of modified tapioca flour and egg white addition on kamaboko form surimi catfish (Pangasius hypopthalmus). Proceedings National Seminar on Fisheries. Fisheries High School. 4-5 December 2010: 11 p.

Slavov. A, Karagyyozov. V, Denev, P, Kratchanova. M. \& Kratchanov, C. (2013) Antioxidant Activity of Red Beet Juices Obtained after Microwave and Thermal Pretreatments. Zech J. Food Sci. 31 (2): 139-147

Tanikawa, E., Motohiro,T., \& Akiba,M. (1985). Marine products in Japan. Koseikha Koseikaku Co Ltd. Tokyo.

Yang, H. \& Park, J.W. (1998). Effects of starch properties and thermal-processing conditions on surimi-starch gels. Lebensm.Wiss. Technol. (31), 344-353.

Yunizal, Mutini, J.T., Dolaria, N., Purdiwoto, B., Abdurokhim, \& Carkipan. (1998). Chemical Analysis Prosedure of Fish and Fish Product. Research Center \& Development of Fisheries. Jakarta. $53 \mathrm{pp}$.

Venugopal, V. (2006). Seafood Processing : Adding Value Through Quick Freezing, Retortable Packaging and Cook-Chilling. CRC Press, Florida, ISBN: 1574446223.

Xiong G, Cheng. W, Ye. L, Du. X. Zhou.X, Zhou.M, Lin. R Geng S. Chen.M, Corke.H. \& Cai. Y.Z. (2009). Effects of konjac glucomanan on physicochemical properties of myofibrillar protein and surimi gels from grass carp (Ctenopharyngodon idella). Food Chemistry (116) : 412-418.

Zhang. F, Fang. L, Wang. C, Shi. L Chang. T, Yang .H \& Cui. M, (2012). Effect of straches on textural, rheological, and colour properties surimi-beef gels with microbial transglutaminase. Meat Science (93): $533-537$ 